\title{
Impact of sandy soil physico-chemical properties towards urban lakes eutrophication and inorganic pollutant status
}

\author{
Rashidi Othman*, Wan Syibrah Hanisah Wan Sulaiman, Zainul Mukrim Baharuddin, \\ Lukman Hakim Mahamod, Khairusy Syakirin Has-Yun Hashim \\ International Institute for Halal Research and Training (INHART), Department of Landscape Architecture, Kulliyyah of Architecture \\ and Environmental Design, International Islamic University Malaysia, 53100 Kuala Lumpur, Malaysia, Tel. +60126644772; \\ email: rashidi@iium.edu.my (R.Othman)
}

Received 10 September 2018; Accepted 26 January 2019

\begin{abstract}
A B S T R A C T
A variety of soil types in Malaysia have contributed to the difference of soil properties dissolved in the water and the concern of soil problem in Malaysia involves laterite, sandy, acid sulphate and organic soil. There are several physical properties have been used to evaluate the water sample and consist of $\mathrm{pH}$, dissolved oxygen, total suspended solids, chemical oxygen demand, biological oxygen demand and ammoniacal nitrogen $\left(\mathrm{NH}_{3}-\mathrm{N}\right)$. For heavy metals, 10 elements had been selected based on Malaysia Environmental Quality Report for further evaluation that consists of ( $\mathrm{Al}, \mathrm{Cr}, \mathrm{Mn}, \mathrm{Fe}$, $\mathrm{Co}, \mathrm{Ni}, \mathrm{Cu}, \mathrm{Zn}, \mathrm{Cd}$ and $\mathrm{Pb}$ ). Physico-chemical properties for water were measured in situ and in the laboratory and further analysis was prepared by using inductively coupled plasma mass spectrometry and analysis of variance (ANOVA) for heavy metals assessment equally for soil and water. The result obtained showed the average of water quality index for sandy soil in the urban lake was in class IV the status of water mostly was polluted as the amount of the high value in BOD $(81.62 \mathrm{mg} / \mathrm{L}), \mathrm{COD}$ $(23.53 \mathrm{mg} / \mathrm{L})$ and $\mathrm{NH}_{3}-\mathrm{N}(0.44 \mathrm{mg} / \mathrm{L})$. The level of TSS was low $(27.18 \mathrm{mg} / \mathrm{L})$ as sandy soil particle less influence for soil movement into the water. As for the result of heavy metals, the composition varied in water but several elements exceeded the natural level such as $\mathrm{Al}(0.07 \mathrm{mg} / \mathrm{L}), \mathrm{Cr}(0.3 \mathrm{mg} / \mathrm{L}), \mathrm{Ni}$ $(0.11 \mathrm{mg} / \mathrm{L}), \mathrm{Cu}(0.02 \mathrm{mg} / \mathrm{L})$ and $\mathrm{Pb}(1.43 \mathrm{mg} / \mathrm{L})$ as responding to the character of porosity in sandy soil. Meanwhile, two significant elements were found in sandy soil which was $\mathrm{Al}(157.95 \mathrm{mg} / \mathrm{kg})$ and $\mathrm{Fe}(156.17 \mathrm{mg} / \mathrm{kg})$ and become a significant signature indicator.
\end{abstract}

Keywords: Sandy soil; Eutrophication; Inorganic pollutant; Urban lakes quality index

\section{Introduction}

There has been a growing concern of urban lake pollution in Malaysia that picture to bad eutrophication as reported by National Institute of Hydraulic Research Malaysia. The report indicated that more than $60 \%$ lakes from 90 numbers that were reviewed experiencing eutrophication [1]. The increasing anthropogenic activities through the rising industrial development has been contributing to environmental degradation including the water and soil contaminants that involve organic and inorganic compound and impacting the stability of physical-chemical properties for soil and water in the urban lake as well as the implications on plants, animals and human health [2]. The ability of soil to bind various chemicals has caused soil and water to be exposed to inorganic contaminants that changes the equilibrium found in soil [3].

Malaysia has a tropical climatic condition and the main agent for soil formation is depending on the climate that impacts from the weathering of parent rocks as well as

* Corresponding author.

This is an Open Access article. Non-commercial re-use, distribution, and reproduction in any medium, provided the original work is properly attributed, cited, and is not altered, transformed, or built upon in any way, is permitted. The moral rights of the named author(s) have been asserted. 
chemical weathering that formatting types of soil in as a result sandy is one of the residual from weathering process in soil formatting [4]. The anxieties from soil and water contaminants have the negative effects on the plant's growth [5] in responding to the porosity of sandy soil that allowed excessive of nutrients to the lake due to run off from the land. Equally important, the negative effect of inorganic compounds that were emitted to the water from the soil as for transmitted agent from human activities and contaminated to the top layer of the soil ranging between 2 and $5 \mathrm{~cm}$ depth and bother the food chain in the soil as well as in water body nearby [6].

Thus, the study on the impact of sandy soil towards urban lakes will focus on the soil physico-chemical properties and inorganic pollutants status for 10 selected urban lakes in Peninsular Malaysia.

\section{Materials and methods}

\subsection{Study area and sampling design}

Most of the area was constructed as ex-mining land area. The samples were collected at 10 points from each site for water from the lake and soil at surrounding the lake. Accordingly, 100 samples were collected for the whole assessment.

- S1: Tasik Puteri Bukit Besi, Terengganu $\left(4^{\circ} 43^{\prime} 57.8^{\prime \prime} \mathrm{N}\right.$ $\left.103^{\circ} 11^{\prime} 30.3^{\prime \prime} \mathrm{E}\right)$

- S2: West Lake Kampar, Perak (4.332584, 101.138062)

- S3: Tasik Malin Nawar, Perak $\left(4^{\circ} 21^{\prime} 05.9^{\prime \prime} \mathrm{N} 101^{\circ} 06^{\prime} 26.1^{\prime \prime} \mathrm{E}\right)$

- S4: Tasik Rakan Muda Kampar, Perak $\left(4^{\circ} 18^{\prime} 31.0^{\prime \prime} \mathrm{N}\right.$ $\left.101^{\circ} 08^{\prime} 38.5^{\prime \prime} \mathrm{E}\right)$

- S5: Tasik Temoh Kampar, Perak $\left(4^{\circ} 14^{\prime} 11.6^{\prime \prime} \mathrm{N} 101^{\circ} 12^{\prime} 03.3^{\prime \prime} \mathrm{E}\right)$

- S6: Tasik UTP Tronoh, Perak ( $\left.4^{\circ} 23^{\prime} 02.2^{\prime \prime} \mathrm{N} 100^{\circ} 58^{\prime} 42.9^{\prime \prime} \mathrm{E}\right)$

- S7: Bandar University Lake Ville Tronoh, Perak $\left(4^{\circ} 21^{\prime} 26.5^{\prime \prime} \mathrm{N}\right.$ $\left.100^{\circ} 58^{\prime} 53.1^{\prime \prime} \mathrm{E}\right)$

- S8: Tasik Unisel Rawang, Selangor (A) $\left(3^{\circ} 24^{\prime} 54.2^{\prime \prime} \mathrm{N}\right.$ $\left.101^{\circ} 26^{\prime} 28.3^{\prime \prime} \mathrm{E}\right)$

- S9: Tasik Unisel Rawang, Selangor (B) $\left(3^{\circ} 24^{\prime} 53.7^{\prime \prime} \mathrm{N}\right.$ $\left.101^{\circ} 26^{\prime} 20.6^{\prime \prime} \mathrm{E}\right)$

- S10: Tasik Unisel Rawang, Selangor (C) $\left(3^{\circ} 25^{\prime} 26.7^{\prime \prime} \mathrm{N}\right.$ $\left.101^{\circ} 27^{\prime} 00.3^{\prime \prime} \mathrm{E}\right)$

\subsection{Water sampling preparation}

Based on the Environmental Quality Report published by the Department of Environment, water quality assessment was evaluated based on six physico-chemical measuring tools, namely $\mathrm{pH}$, dissolved oxygen (DO), biological oxygen demand (BOD) and chemical oxygen demand (COD), total suspended solids (TSS) and ammoniacal nitrogen $\left(\mathrm{NH}_{3}-\mathrm{N}\right)$. The water sample was collected $10 \mathrm{~cm}$ depth from the water surface for a total of 100 samples from 10 different areas of urban lakes at sandy soil land area [7]. There is 10 point of water sampling collected for each lake from March to April and the characteristic of water bodies should be stagnant that called as a lake or reservoir. The analysis of heavy metals was conducted by digesting $45 \mathrm{~mL}$ water sample with $5 \mathrm{~mL}$ nitric acid $65 \%$ in a closed vessel of microwave digester D start at 1,500 W maximum power for 10 vessels for $20 \mathrm{~min}$ heating before further analysis with inductively coupled plasma mass spectrometry (ICP-MS).

\subsection{Soil sampling and preparation}

For soils sampling the same location were used at 10 selected points and the distance was $1 \mathrm{~m}$ from the lakeside with $30 \mathrm{~cm}$ depth. The sample was homogenized in one container before the next process. In the laboratory, the sample was air-dried at $60^{\circ} \mathrm{C}$ and sieve at $2.0 \mathrm{~mm}$ after ground for further dry $\mathrm{pH}$, organic carbon (OC) and cation exchange capacity (CEC) analysis. $0.5 \mathrm{~g}$ of soil samples were accurately weighed into a container made of PFA perfluoroalkoxy polymer and digested through a microwave digestion system using the digestion method as detailed in Method US EPA 3051. Dried and the ground sample was mixed with $10 \mathrm{~mL}$ of concentrated nitric acid $\left(\mathrm{HNO}_{3} 65 \%\right)$ and digested. Acid was added for each soil samples and then the digestion tubes were placed in a rotor segment by using a torque wrench. The segments were inserted into the microwave cavity and connected with the temperature sensor. The mixture temperature was adjusted to $\pm 175^{\circ} \mathrm{C}$ and 1,500 Watt of maximum power for $35 \mathrm{~min}$ using Microwave Digestion Ethos D. The complete solution was then used for further analysis of heavy metals (Al, Cr, Mn, Fe, Co, Ni, Cu, Zn, Cd and $\mathrm{Pb}$ ) content in soil by using ICP-MS.

\section{Results}

\subsection{Physico-chemical properties analysis}

The texture fraction of soil sample is shown in Table 1. The highest fraction of soil texture for the overall sample was coarse sand, which ranged from $17 \%$ to $86 \%$ and followed by fine sand $5 \%-43 \%$. For clay, the ranges were between $9 \%$ and $25 \%$ and for silt the ranged from $1 \%$ to $19 \%$. Hence, the average for all samples was dominant by coarse sand and fine sand that cover $82.5 \%$ for both. Further analysis was conducted for dry $\mathrm{pH}, \mathrm{OC}, \mathrm{CEC}$ and calcium and found most of the average of $\mathrm{pH}$ were acidic with ranged between 4.37 and 6.66. The percentages of $\mathrm{OC}$ were very low as average was only $0.33 \%$ and same goes to CEC with average value only $3.09 \mathrm{~mol} / \mathrm{kg}$. Meanwhile, the value of calcium found varied in ranged between 0.01 and $10.06 \mathrm{mg} / \mathrm{kg}$ and as the average of $0.28 \mathrm{mg} / \mathrm{kg}$.

Other than that, physico-chemical analysis for water in urban lake shows a significant result as referred to Table 2 on six parameters for BOD with average value $82.62 \mathrm{mg} / \mathrm{L}$, $\mathrm{COD}(23.52 \mathrm{mg} / \mathrm{L})$ and $\mathrm{NH}_{3}-\mathrm{N}(0.44 \mathrm{mg} / \mathrm{L})$. The level of TSS was very low with value $27.18 \mathrm{mg} / \mathrm{L}$ as sandy soil particle less influence for soil movement into the water. The overall $\mathrm{pH}$ of the water was found in acidic with an average 5.91 and percentage of saturation dissolved oxygen average was $13.09 \mathrm{mg} / \mathrm{L}$.

\subsection{Heavy metals analysis in the urban lake at sandy soil land area}

The result of heavy metals analysis from ICP-MS showed several elements as presented in Table 3 were identified as an indicator for water assessment in a sandy soil area. The significant elements that were found consist of $\mathrm{Cr}$ (0.3 mg/L), Al (0.07 mg/L), Pb (1.43 mg/L), Ni (0.11 mg/L) and $\mathrm{Cu}(0.02 \mathrm{mg} / \mathrm{L})$. Meanwhile, the concentration of heavy 
Table 1

Distribution of soil physico-chemical properties for sandy soil

\begin{tabular}{|c|c|c|c|c|c|c|c|c|}
\hline Location & $\begin{array}{l}\text { Dry } \\
\text { pH }\end{array}$ & $\begin{array}{l}\text { OC } \\
(\mathrm{mg} / \mathrm{L})\end{array}$ & $\begin{array}{l}\text { CEC } \\
(\mathrm{mol} / \mathrm{kg})\end{array}$ & $\begin{array}{l}\mathrm{Ca} \\
(\mathrm{mg} / \mathrm{kg})\end{array}$ & $\begin{array}{l}\text { Coarse } \\
\text { sand }(\%)\end{array}$ & $\begin{array}{l}\text { Fine } \\
\text { sand }(\%)\end{array}$ & $\begin{array}{l}\text { Silt } \\
(\%)\end{array}$ & $\begin{array}{l}\text { Clay } \\
(\%)\end{array}$ \\
\hline S1 & 5.13 & 0.97 & 10.06 & 1.07 & 17 & 43 & 19 & 25 \\
\hline S2 & 6.59 & 0.59 & 0.83 & 1.54 & 50 & 24 & 8 & 24 \\
\hline S3 & 6.52 & 0.25 & 0.83 & 0.06 & 69 & 26 & 1 & 9 \\
\hline S4 & 6.03 & 1.06 & 4.68 & - & 60 & 22 & 6 & 17 \\
\hline S5 & 6.66 & 0.21 & 3.72 & 0.01 & 62 & 19 & 8 & 14 \\
\hline S6 & 6.48 & 0.27 & 1.36 & - & 60 & 31 & 2 & 11 \\
\hline S7 & 5.27 & 0.2 & 1.33 & 0.01 & 73 & 22 & 1 & 9 \\
\hline S8 & 4.53 & 0.11 & 1.79 & 0.02 & 61 & 23 & 7 & 14 \\
\hline S9 & 4.37 & 0.45 & 4.28 & 0.05 & 48 & 24 & 12 & 19 \\
\hline S10 & 4.45 & 0.36 & 2.03 & 0.02 & 86 & 5 & 4 & 12 \\
\hline Mean & 5.6 & 0.45 & 3.09 & 0.28 & 58.6 & 23.9 & 6.8 & 15.4 \\
\hline Standard deviation & 0.96 & 0.33 & 2.83 & 0.55 & 18.27 & 9.48 & 5.55 & 5.76 \\
\hline
\end{tabular}

Table 2

Physico-chemical analysis on water for sandy soil

\begin{tabular}{llllllll}
\hline Loc & $\mathrm{pH}$ & $\mathrm{DO}(\mathrm{mg} / \mathrm{L})$ & $\mathrm{BOD}(\mathrm{mg} / \mathrm{L})$ & $\mathrm{COD}(\mathrm{mg} / \mathrm{L})$ & $\mathrm{TSS}(\mathrm{mg} / \mathrm{L})$ & NH3-N $(\mathrm{mg} / \mathrm{L})$ & WQI Class \\
\hline S1 & $4.5 \pm 0.12$ & $35.88 \pm 10.18$ & $44.16 \pm 3.72$ & 0 & $2.28 \pm 1.81$ & $0.38 \pm 0$ & Class III \\
S2 & $6.61 \pm 0.17$ & $17.9 \pm 3.83$ & $69.57 \pm 2.48$ & $22.67 \pm 6.81$ & $38.46 \pm 1.82$ & $0.95 \pm 1.86$ & Class IV \\
S3 & $6.68 \pm 0.17$ & $13.54 \pm 2.85$ & $68.21 \pm 2.06$ & $27.67 \pm 2.08$ & $185.11 \pm 3.48$ & $0.8 \pm 0.06$ & Class IV \\
S4 & $6.28 \pm 0.18$ & $10.27 \pm 3.46$ & $73.11 \pm 2.95$ & $1.33 \pm 2.3$ & $11 \pm 1.22$ & $0.75 \pm 0.19$ & Class IV \\
S5 & $7.2 \pm 0.15$ & $20.1 \pm 4.41$ & $71.14 \pm 1$ & $2.33 \pm 4.04$ & $3.7 \pm 1.67$ & $0.28 \pm 0.01$ & Class III \\
S6 & $6.57 \pm 0.23$ & $4.77 \pm 1.6$ & $94.89 \pm 8.71$ & $14.33 \pm 2.52$ & $162.74 \pm 4.89$ & $0.12 \pm 0.1$ & Class IV \\
S7 & $6.58 \pm 0.32$ & $5.32 \pm 1.14$ & $96.49 \pm 8.96$ & $14 \pm 4.36$ & $5.64 \pm 1.14$ & $0.28 \pm 0$ & Class IV \\
S8 & $4.57 \pm 0.47$ & $5.48 \pm 0.33$ & $121.39 \pm 15.65$ & $41 \pm 7$ & $5.13 \pm 0.92$ & $0.14 \pm 0.11$ & Class IV \\
S9 & $4.67 \pm 0.32$ & $7.03 \pm 0.53$ & $88.61 \pm 10.81$ & $34.67 \pm 10.79$ & $13.04 \pm 1.79$ & $0.24 \pm 0.05$ & Class IV \\
S10 & $5.87 \pm 0.06$ & $4.47 \pm 0.29$ & $88.61 \pm 10.81$ & $77.33 \pm 6.51$ & $1.16 \pm 1.02$ & $0.42 \pm 0.09$ & Class IV \\
Average & $5.91 \pm 0.98^{*}$ & $13.09 \pm 9.86^{*}$ & $81.62 \pm 21.05^{*}$ & $23.53 \pm 23.6^{*}$ & $27.18 \pm 56.54^{*}$ & $0.44 \pm 0.29^{*}$ & Class IV \\
\hline
\end{tabular}

*Analysis of variance (ANOVA $p<0.0001$ ).

WQI = Water quality index, Class I = Conservation of natural environment (Water Supply I: Practically no treatment necessary, Fishery I: Vey sensitive aquatic species), Class IIA = (Water Supply II: Conventional treatment required, Fishery II: Sensitive aquatic species), Class IIB = Recreational use with body contact, Class III: (Water Supply III; Extensive treatment required, Fishery III: Common of economic value and tolerant species, livestock drinking), Class IV = Irrigation, Class V = None of the above.

metals elements was found higher in soil sample was in $\mathrm{Al}$ $(157.95 \mathrm{mg} / \mathrm{kg})$ and Fe $(156.17 \mathrm{mg} / \mathrm{kg})$ as showed in Table 4.

\section{Discussion}

\subsection{Impact of sandy soil physico-chemical properties towards urban lake eutrophication}

As shown in the analysis above, the value of soil $\mathrm{pH}$ and OC plays a vital role in the determination of water quality classification in an urban lake. The result showed that most of the soil sample were acidic and it probably as a result of CEC activity [8]. However, the soil fractions of CEC for sandy soil were in range as compared with the result [3]. For instance, the character of sandy soil that often by lower carbon and high concentration of alkyl influences the soil movements and indirectly impact the $\mathrm{pH}$ of the water and the DO that was found very low. The percentage of clay and organic matter has impacted the velocity of water draining to the lake as the soil cannot retain so much water [9] and it was impacted the result of TSS in urban lake by measuring the solid matter suspended in water that consist of organic and inorganic material and waste [10].

Another factor that influences the low $\mathrm{pH}$ in water in all selected sandy urban lake area is the land use changes such as ex-mining as similar occurred at most of the site [5]. The reflection of the low value of $\mathrm{pH}$ in water indicates the high value in COD and BOD as appeared in the result above. It is also interconnected to the DO\% saturation to the value of BOD [11]. On top of that, another significant source of eutrophication was the value of $\mathrm{NH}_{3}-\mathrm{N}$ [12]. The analysis of data found that the value of $\mathrm{NH}_{3}-\mathrm{N}$ has affected the 
Table 3

Analysis of heavy metals concentration for water at a sandy soil area

\begin{tabular}{lllllllllll}
\hline Area & $\begin{array}{l}\mathrm{Al} \\
(\mathrm{mg} / \mathrm{L})\end{array}$ & $\begin{array}{l}\mathrm{Cr} \\
(\mathrm{mg} / \mathrm{L})\end{array}$ & $\begin{array}{l}\mathrm{Mn} \\
(\mathrm{mg} / \mathrm{L})\end{array}$ & $\begin{array}{l}\mathrm{Fe} \\
(\mathrm{mg} / \mathrm{L})\end{array}$ & $\begin{array}{l}\mathrm{Co} \\
(\mathrm{mg} / \mathrm{L})\end{array}$ & $\begin{array}{l}\mathrm{Ni} \\
(\mathrm{mg} / \mathrm{L})\end{array}$ & $\begin{array}{l}\mathrm{Cu} \\
(\mathrm{mg} / \mathrm{L})\end{array}$ & $\begin{array}{l}\mathrm{Zn} \\
(\mathrm{mg} / \mathrm{L})\end{array}$ & $\begin{array}{l}\mathrm{Cd} \\
(\mathrm{mg} / \mathrm{L})\end{array}$ & $\begin{array}{l}\mathrm{Pb} \\
(\mathrm{mg} / \mathrm{L})\end{array}$ \\
\hline S1 & - & - & - & - & - & - & - & - & - & - \\
S2 & 0.02 & - & 0.02 & 0.06 & - & - & - & 0.01 & - & - \\
S3 & 0.02 & - & 0.05 & 0.23 & - & - & - & 0.01 & - & - \\
S4 & 0.03 & - & 0.01 & 0.13 & - & - & - & 0.02 & - & - \\
S5 & - & - & 0.01 & 0.01 & - & - & - & 0.01 & - & - \\
S6 & - & - & - & 0.02 & - & - & - & - & - & - \\
S7 & 0.54 & 2.90 & 0.30 & 0.44 & 0.12 & 1.00 & 0.23 & 0.19 & 0.55 & 14.26 \\
S8 & - & 0.03 & 0.01 & 0.31 & - & 0.02 & - & - & - & - \\
S9 & 0.03 & 0.03 & 0.01 & 0.32 & - & 0.02 & - & 0.01 & - & - \\
S10 & 0.03 & 0.03 & 0.01 & 0.32 & - & 0.02 & - & 0.01 & - & - \\
Mean & $\mathbf{0 . 0 7 *}$ & $\mathbf{0 . 3 0}$ & $\mathbf{0 . 0 4}$ & $\mathbf{0 . 1 8}$ & $\mathbf{0 . 0 1}$ & $\mathbf{0 . 1 1}$ & $\mathbf{0 . 0 2 *}$ & $\mathbf{0 . 0 3}$ & $\mathbf{0 . 0 6}$ \\
Standard deviation & 0.17 & 0.91 & 0.09 & 0.16 & 0.04 & 0.31 & 0.07 & 0.06 & 0.17 & $\mathbf{1 . 4 3}$ \\
Class & $\mathrm{IV}$ & $\mathrm{V}$ & $\mathrm{I}$ & $\mathrm{I}$ & $\mathrm{I}$ & $\mathrm{III}$ & $\mathrm{IIA} / \mathrm{IIB}$ & $\mathrm{I}$ & $\mathrm{I}$ & IV \\
\hline
\end{tabular}

*Analysis of variance (ANOVA $p<0.0001$ )

Table 4

Analysis of heavy metals concentration for soil at sandy land area

\begin{tabular}{|c|c|c|c|c|c|c|c|c|c|c|}
\hline Area & $\begin{array}{l}\mathrm{Al} \\
\mathrm{mg} / \mathrm{kg}\end{array}$ & $\begin{array}{l}\mathrm{Cr} \\
\mathrm{mg} / \mathrm{kg}\end{array}$ & $\begin{array}{l}\mathrm{Mn} \\
\mathrm{mg} / \mathrm{kg}\end{array}$ & $\begin{array}{l}\mathrm{Fe} \\
\mathrm{mg} / \mathrm{kg}\end{array}$ & $\begin{array}{l}\text { Co } \\
\mathrm{mg} / \mathrm{kg}\end{array}$ & $\begin{array}{l}\mathrm{Ni} \\
\mathrm{mg} / \mathrm{kg}\end{array}$ & $\begin{array}{l}\mathrm{Cu} \\
\mathrm{mg} / \mathrm{kg}\end{array}$ & $\begin{array}{l}\mathrm{Zn} \\
\mathrm{mg} / \mathrm{kg}\end{array}$ & $\begin{array}{l}\mathrm{Cd} \\
\mathrm{mg} / \mathrm{kg}\end{array}$ & $\begin{array}{l}\mathrm{Pb} \\
\mathrm{mg} / \mathrm{kg}\end{array}$ \\
\hline S1 & 232.72 & 0.46 & 1.60 & $1,010.66$ & 0.03 & 0.43 & 0.34 & 2.05 & - & 0.16 \\
\hline S2 & 548.91 & 0.09 & 1.93 & 156.49 & 0.06 & 0.97 & 0.19 & 2.23 & 0.03 & 0.83 \\
\hline S3 & 212.80 & 0.31 & 0.41 & 20.46 & 0.01 & 0.31 & 0.01 & 1.32 & - & 0.21 \\
\hline S4 & 9.38 & 0.01 & 0.03 & 3.86 & - & 0.01 & - & 0.02 & - & 0.00 \\
\hline S5 & 22.10 & - & 0.09 & 5.50 & - & 0.01 & - & - & - & 0.00 \\
\hline S6 & 23.33 & 0.05 & 0.06 & 8.14 & - & 0.01 & - & 0.08 & - & 0.01 \\
\hline S7 & 8.18 & 0.03 & 0.02 & 3.83 & - & 0.04 & - & 0.01 & - & 0.00 \\
\hline S8 & 47.88 & 0.24 & 0.22 & 48.49 & - & 0.27 & 0.11 & 0.35 & - & 0.06 \\
\hline S9 & 302.85 & 0.04 & 1.29 & 274.22 & 0.03 & - & 0.07 & 0.26 & - & 0.22 \\
\hline S10 & 171.40 & - & 0.25 & 30.05 & 0.00 & 0.02 & 0.04 & 0.11 & - & 0.11 \\
\hline Mean & $157.95^{*}$ & $0.12^{*}$ & $0.59^{*}$ & $156.17^{*}$ & $0.01^{*}$ & $0.21^{*}$ & $0.08^{*}$ & $0.64^{*}$ & - & $0.16^{*}$ \\
\hline Standard deviation & 175.06 & 0.16 & 0.73 & 312.88 & 0.02 & 0.31 & 0.11 & 0.88 & 0.01 & 0.25 \\
\hline
\end{tabular}

*Analysis of variance (ANOVA $p<0.0001$ ).

classification of water quality in most of the sample. Besides, the analysis of calcium content in a soil sample is low as a result of reaching saturation levels that affected from evaporation process or other human activities [13]. Hence, the value of physico-chemical properties from soil and water can indicate the status of urban lake pollutants.

\subsection{Impact of sandy soil physico-chemical properties towards inorganic pollutant status}

Heavy metals compound is one of the components from inorganic pollutants as impacted by anthropogenic activities by human to the environments and the high solubility in water ecosystem will harm a living organism [14]. Heavy metals were known as trace elements in water that should be present in small concentration and an excessive amount may cause unsuitable for human use and toxicity for other living things [15]. Based on the assessment of heavy metals analysis by using ICP-MS and the comparison between the water quality index (WQI) statuses, the highest status of heavy metals content in water was $\mathrm{Cr}$ that was placed under the class $\mathrm{V}$ and followed $\mathrm{Al}$ and $\mathrm{Pb}$ placed under class IV. The other two elements that were a concern were $\mathrm{Ni}$ and $\mathrm{Zn}$ that were placed under the class IIA/B. All five elements have impacted the water quality in the urban lake and the status was out of natural range for water quality. The loading of three elements which were $\mathrm{Cr}, \mathrm{Cu}$ and $\mathrm{Ni}$ in water were in agreement in another study that discovered the deciphering heavy metal contamination in soils of a granitic of southern India that was caused by anthropogenic activities and the land use changes that influence the solubility, toxicity as well as mobility of heavy metals [16]. The worse heavy metals 
concentration impacted urban lake status based on WQI classification was the value of $\mathrm{Cr}$ which was placed under class $\mathrm{V}$ and exceeded the standard. The standards were referred to the National Water Quality Standards for Malaysia that was published in Malaysia Environmental Quality Report. Other than that, the main source of $\mathrm{Cr}$ contamination was from steel-producing industries, chrome plating and industrial waste [16]. Other sources from agricultural soil were inorganic fertilizer, atmospheric deposition, sewage sludge and also livestock manure [17]. $\mathrm{pH}$ of water significantly affects the solubility of free metal concentration in the water sample as the metals ion increases, $\mathrm{pH}$ increases. The existence of various heavy metals in water sample was contributed to the pollutant status.

Further analysis of heavy metals for soil was conducted and showed the dominant heavy metals concentration found in sandy soil was $\mathrm{Al}$ and Fe. The level of $\mathrm{Al}$ in a soil sample is kind of alarming to the aquatic living because the dissolution of aluminium oxide in sediment from the soil will run into the water bodies and particularly dangerous for fish [13]. Change in land use plays an important role in changing the quality of water and soil of the area. Land use changes strongly influence soil moisture regime and soil Eh which could greatly affect solubility, toxicity, bioavailability and mobility of heavy metals and cause their redistribution in soils. Furthermore, it is possible to get associations or information about the behaviour and the source of pollution of heavy metals [16]. Different doses of heavy metals in water and soil sample that expose and increase is a basis of environmental negative impact, but some of the aquatic plants have an ability to absorb the heavy metals that associated with contaminants and reducing the content of heavy metals into the urban lake [18]. The composition of soil texture that consists of $15.4 \%$ clay and 6.8 silt can be a factor that binds the inorganic substances in clay and silt soil and reduced before entering the water bodies [3].

\section{Conclusion}

In conclusion, physico-chemical properties of sandy soil land area have many factors that impact the overall status of quality of the urban lake. This study has obtained the average WQI classification for sandy soil was in class IV with the high value in BOD $(81.62 \mathrm{mg} / \mathrm{L}), \mathrm{COD}(23.53 \mathrm{mg} / \mathrm{L})$ and $\mathrm{NH}_{3}-\mathrm{N}(0.44 \mathrm{mg} / \mathrm{L})$. In particular, the texture of sandy soil that was porosity influencing the movement of water run off to the water bodies and expose more heavy metal elements associated with contaminants. As a result, the level of TSS was low $(27.18 \mathrm{mg} / \mathrm{L})$ as sandy soil particle less influence for soil movement into the water. However, the result of heavy metals concentration in urban lake is varied and several elements exceeded the natural level such as $\mathrm{Al}(0.07 \mathrm{mg} / \mathrm{L}), \mathrm{Cr}(0.3 \mathrm{mg} / \mathrm{L}), \mathrm{Ni}(0.11 \mathrm{mg} / \mathrm{L}), \mathrm{Cu}$ $(0.02 \mathrm{mg} / \mathrm{L})$ and $\mathrm{Pb}(1.43 \mathrm{mg} / \mathrm{L})$. In the meantime, two significant elements were found in sandy soil which was Al $(157.95 \mathrm{mg} / \mathrm{kg})$ and Fe $(156.17 \mathrm{mg} / \mathrm{kg})$ and becomes as a signature indicator. This result is significant for water quality monitoring programme in minimizing the water quality degradation in Malaysia and eutrophication adverse impact.

\section{Acknowledgements}

The authors acknowledge financial support by International Islamic University Malaysia (IIUM) and Ministry of High Education (MOHE) through Research Grant MOHE 18-001-0001.

\section{References}

[1] Z. Sharip, S. Zakaria, Lakes and Reservoir in Malaysia: Management and Research Challenges, Proceeding of Taal2007: The 12th World Lake Conference, ILEC (International Lake Environment Committee), Japan, 2008, pp. 1349-1355.

[2] N. Shabani, M.H. Sayadi, Evaluation of heavy metals accumulation by two emergent macrophytes from the polluted soil: an experimental study, Environmentalist, 32 (2012) 91-98.

[3] A. Dube, R.Z.T. Kowalkowski, E. Cukrowska, B. Buszewski, Adsorption and migration of heavy metals in soil, Pol. J. Environ. Stud., 10 (2001) 1-10.

[4] B. Kim Huat, Problematic Soils, Universiti Putra Malaysia Press, Serdang, 2010.

[5] M.A. Ashraf, M.J. Maah, I.B. Yusoff, Study of water quality and heavy metals in soil \& water of ex-mining area Bestari Jaya, Peninsular Malaysia, Int. J. Basic Appl. Sci., 10 (2010) 7-23.

[6] J.S. Succuro, S.S. Mcdonald, C.R. Lu, Phytoremediation: the wave of the future, Recent Adv. Plant Biotechnol., 2 (2009) 119-135.

[7] I.M. Sujaul, M.A. Sobahan, A.A. Edriyana, F.M. Yahaya, R.M. Yunus, Adverse impacts of poor wastewater management practices on water quality in Gebeng Industrial Area, Pahang, Malaysia, Int. J. Environ. Ecol. Geol. Geophys. Eng., 9 (2015) 286-289.

[8] R. Othman, S.H. Hasni, Z.M. Baharuddin, Analysis of heavy metals as a key indicator to predict shallow slope failure, J. Environ. Biol., 37 (2016) 1181-1185.

[9] M. Ashraf, M. Ozturk, M. Sajid, A. Ahmad, Plant Adaptation and Phytoremediation, Springer, Dordrecht, Heidelberg, London, New York, 2010.

[10] I. Mohamed, F. Othman, A.I.N. Ibrahim, M.E. Alaa-Eldin, R.M. Yunus, Assessment of water quality parameters using multivariate analysis for Klang River basin, Malaysia, Environ. Monit. Assess., 187 (2015) 4182.

[11] S. Jodeh, M. Salim, M. Haddad, Impacts of biodegradable organics on soils and groundwater in West Bank, J. Assoc. Arab Univ. Basic Appl. Sci., 14 (2013) 75-82.

[12] M.A. Hossain, I.M. Sujaul, M.A. Nasly, Water quality index: an indicator of surface water pollution in eastern part of Peninsular Malaysia, Res. J. Recent Sci., 2 (2013) 10-17.

[13] D. Chapman, Water Quality Assessments - A Guide to Use of Biota, Sediments and Water in Environmental Monitoring, University Press, Cambridge, 1996.

[14] M.A. Barakat, New trends in removing heavy metals from industrial wastewater, Arabian J. Chem., 4 (2011) 361-377.

[15] C.E. Boyd, Water Quality, An Introduction, Kluwer Academic Publishers, Boston, 2000.

[16] D. Purushotham, M.A. Lone, M. Rashid, A. Narsing Rao, S. Ahmed, Deciphering heavy metal contamination zones in soils of a granitic terrain of southern India using factor analysis and GIS, J. Earth Syst. Sci., 121 (2012) 1059-1070.

[17] P.S. Hooda, Trace Elements in Soil, John Wiley and Sons Ltd. Publications, UK, 2010.

[18] T.J. Purakayastha, P.K. Chhonkar, In: I. Sherameti, A. Varma, Eds., Soil Biology: Soil Heavy Metals, Vol. 19, Springer-Verlag, Berlin Heidelberg, 2010. 